\title{
A Reading of Shakespeare's Three Female Characters - Hermione, Portia and Calpurnia
}

\section{Silvia P Deenadhayalan}

Research Scholar

India

pdsilviavoc@gmail.com

(A statement) is sexist if it contributes to, encourages or causes or results in the oppression of women. (Mills 83).

For many years, humanity has been ruled by a patriarchal society. In the male dominated society, women have been viewed as objects, marginals, subalterns or inferior human beings. Shakespeare's tragedies are monolithic and the heroes occupy the centre and the women characters get a subordinated treatment. The heroes are given a free 'voice' but the women are simply their 'echo'.

The women characters taken here for analysis are Hermione, Portia and Calpurnia from The Winter's Tale and Julius Caesar. Shakespeare's language is highly phallocentric. Leontes, Brutus and Caesar have the dominating role as husbands. In Shakespearean tragedies, the tragic heroes are the architects of their own sufferings. But the female characters taken into account suffer because of their marginalized place in the structure of power in relation to the male characters.

Among the three, the most helpless is Hermione. In the opening of The Winter's Tale Leontes compels his wife Hermione to persuade Polixenes, "Tongue- tied our queen? Speak you" (WT 1. 2. 28) when he announces his return to Bohemia. As Gayatri Spivak says, Hermione, the margin is at the service of Leontes, the centre. The women are treated as 
margins 'the other'. Spivak says, "Margin is at the service of the centre. The centre wants an identifiable margin, claims for marginality assure validation from the centre."(qtd in Leela Gandhi 84) Both Leontes and Hermione try to encourage Polixenes to extend his stay. When Hermione's entreaties work, he becomes unaccountably suspicious and flies into a jealous rage that shatters the rest of their collective lives.

In the male dominated society "there are not two genders. There is only one, the feminine, the masculine not being a gender. For the masculine is not the masculine but the general." (Sara Mills 45) Men are the norm and women are defined in relation to them.

Leontes' jealousy makes him doubt and repudiate his childhood friendship and drives him to the extent of poisoning Polixenes. Venom in heart, he outwardly praises Hermione for making his friend stay back. She too in her innocence says, "Our praises are our wages. You may ride's with one soft kiss." (WT 1. 2. 94-95). As in the words of Virginia Woolf these words are 'made by a man', the dramatist. Leontes feels that he is cuckolded. The male dominance imprisons Hermione. The male ego does not allow her to voice forth her side. As a king, not as a husband, he commands, "Away with her, to prison." (2. 1. 103) He snatches Mamillius, the prince from her. The man in him generalises," many a man there is (even at this present, now while I speak this) holds his wife by the arm, that little thinks that she has been sluic'd in 's absence.” (1. 2. 191-193)

Dowden says, "Hermione is suspected of a sudden, and shameless dishonour." (qtd in WT 177) Leontes' 'comet- like jealousy' affects both Hermione, the wife and Perdita, his innocent daughter. The male centered world considers woman as possession and as their property, an object. As a possession their loyalty is questioned by using 'honor', a malecentered construct, as a term of reference which the male uses to keep the 'female' under subjugation. This honour, a male centered construct is used as yardstick to measure a woman and it is this construct that gives birth to a violent language Leontes' language is loaded with 
violence. Taking 'honour' as a norm Hermione is considered as a deviant by being branding 'an adulteress' and a 'bed- swerver'. This is the worst charge that could be levelled against a woman. While commenting upon the man-woman relationship Simon d' Beauvoir says, "A man enforces chastity upon woman" (Beauvoir 221). When Leontes charges Hermione with adultery she helplessly cries," You speak of a language that I understand not". (WT 3. 2. 80) Hermione is totally shattered by the atomic energy released from the violent language used by Leontes. Before passing a verdict the charged must be given a chance to defend but Hermione being a woman is denied an opportunity to refute the charge and vindicate her honour.

As the head of the family Leontes decides the destiny of his as well as his people. Antigonus cautions him saying that, "your justice proves violence, in which the three great ones suffer, yourself, your queen, your son." (1. 2. 300) This violence in terms of justice is perfomative.

Leontes has neither the patience to wait for the oracle nor does he give credence to it. He fixes on the oracle the construct he has in mind. "There is no truth at all $i$ ' th' Oracle" (3. 2. 140), he shouts. The verdict of the oracle is that he would die without an heir. But when Hermione swoons he sees before him the fall out of his hasty, uninformed thoughtless decision. Hermione, in the view of Leontes, is the agent through which the lineage gets perpetuated and it is this fact that forces him to go in for reconciliation.

In the statue scene, when Hermione is brought to the court in the form of a statue, Leontes overwhelmed with joy and astonishment tries to kiss her. Paulina prevents him saying, "you will mar it if you kiss it." (5. 3. 83) This can be seen as symbolic of Leontes' power in deciding, to make or mar Hermione's future.

In deploying the device soliloquy Shakespeare shows bias, discriminates between men and women. Whereas in other plays he uses soliloquies in a psychological moment to air 
the view of the heroes, he does not in general use the same device when it comes to the question of a psychological moment in the case of women characters. The device as used by Shakespeare shows the bias on the part of the dramatist.

Hermione as a character is allowed to bustle in and bustle out only in a few scenes, though the play is mainly concerned with the sad fate that over takes her but blossoms into a happy ending.

In the plays Antony and Cleopatra and Romeo and Juliet the dramatist has given equal importance to the respective heroines by making them a part of the title whereas in Julius Caesar the treatment given to Calpurnia is evident in the title itself. She is portrayed as a typical wife - gentle and submissive. She is not the 'conqueror of the conqueror of the world'.

In the Lupercalia festival Caesar reminds Antonius to touch Calpurnia so that she will be cured of her barrenness. This belief in the impregnating touch sounds highly phallocentric - that male is regarded as a giver and female as a receiver. When Caesar goes to the capitol Calpurnia pleads with him not to stir out that day because that day does not augur well for him, if the portends of the previous night are to be believed. Her persuasive words fail to bring change in his decision. She is denied the legitimate right to be a part of the decision making. In an authoritative tone he affirms, "Caesar shall forth". (JC 2. 2. 10) Though she tries to be assertive her language is not aggressive but only submissive. "I never stood on ceremonies, yet now they fright me." (13) But she is not at all listened to by Caesar. He ignores and brushes aside her words as born of the superstitious belief. The 'male' in him asserts that "yet Caesar shall go forth". (29) Even though he wants to stay back, he is afraid of the imputation of fear that might attach to him. And that makes him ignore her solicitude for her husband. She tells him 'call it my fear'. Virginia Woolf in one of her essays says that language is gendered. Brutus slants Calpurnia's dream and convinces Caesar to capitol. Here also Calpurnia's voice is silenced whereas Brutus' is listened to. After the assassination of 
Caesar Antony's rhetoric wins the mob and turns them against Brutus. The dramatist has given a prosaic form of language to Calpurnia so that it does not bring any emotional appeal and it is simply brushed aside by Caesar. The attitude of both is indicative of gender oriented treatment. Brutus' attitude is logical whereas Calpurnia's is emotional. Women's speech is characterised "as more hesitant, less fluent, less logical, less assertive than man's speech." (Mills 45)

At the dawn of the Ides of March Brutus is restless and rolling uneasily in his bed. Sensing that something is bothering her husband, Portia, too is ill at ease. Noticing the arrival of the conspirators with the faces muffled it is clear to her that something terrible is weighing on her husband's mind. As a devoted wife she expects him to confide in her. Besides being the wife of Lord Brutus she is the daughter of Cato, the great Republican. So she thinks that she deserves to know what lies in the recesses of his heart. As a life partner he should have shared his mind. But the male centered notion that women would betray secrets makes him keep quiet. She demands "You have some sick offence in your mind, which, by the right and virtue of my place, I ought to know of" (JC 2. 1. 269-270). But her repeated entreaties only proved to be futile. Within the bond of marriage both husband and wife are expected neither to hush nor hide anything from the other. But the marriage vow is short-shrifted. Hence Portia's outburst, "Within the bond of marriage ... If it be no more, Portia is Brutus' harlot, not his wife." (287) She tries to prove her courage by inflicting upon her thigh a voluntary wound with a knife. She means to say that if she can bear the agony, she can equally share and bear the responsibility of her husband too. Even though of equal mettle and stout of heart she is not given the due that she deserves. Her concern is to be of equal partner in both the fortune and misfortune of her man and not worming out the secret. But Brutus' insouciance drives her to her death which is not an act of cowardice. Through her valiant death she proves that she in no way can be inferiorised. 
All the three women taken for analysis are portrayed as satellites orbiting around their men, having no existence apart from their husbands. Their identity is erased in the male centered world. They are cast into a submissive role by the dramatist in keeping with the gender role accorded by the social pattern then prevalent. In any play the characters are made of words. In these two plays while the male characters are discussed in terms of their trustworthiness and their strength, the female characters are discussed in terms of their unreliableness and their weakness. Besides, the female characters are not given equal space in the discourse scripted by a male. This uneven, lop- sided, biased treatment forces us to brand Shakespeare as a sexist in his use of language loaded against women. 


\section{Works Cited}

de, Beauvoir, Simone. The Second Sex. London: Vintage Publishers, 1997.

Gandhi, Leela. Postcolonial Theory. New Delhi: Oxford University Press, 1998.

Jain, Jasbir and Supriya Agarwal, ed. Gender and Narrative. New Delhi: Rawat Publications, 2002.

Mills, Sara. Feminist Stylistics. London and New York: Routledge, 1998.

Shakespeare, William. Julius Ceasar. Bangalore: Select Publishing House, 1955. The Winter's Tale. London and New York: Methuen, 1966.

Woolf, Virginia. A Room of One's Own. New Delhi: Cambridge University Press, 1998. 